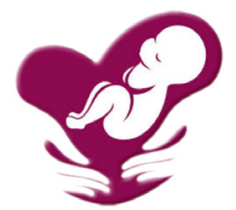

Published by DiscoverSys

\section{The effect of antibiotic therapy on Salivary Catalase kinetic parameters in neonatal at risk of Sepsis}

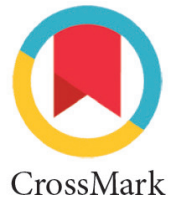

\author{
Ari Yunanto ${ }^{1}$, Pricilia Gunawan Halim ${ }^{1 *}$, Iskandar ${ }^{1}$, Eko Suhartono ${ }^{2}$
}

parameters are represented by the Michaelis-Menten constant $(\mathrm{Km})$ and the maximum reaction speed ( $\mathrm{m}$ max) obtained through the Lineweaver-Burk curve plot.

Results: The $\mathrm{Km}$ of Catalase on the saliva of neonates at risk of sepsis treated with antibiotics (4.37, 1.84, 0.12, and 0.23, 3.74, 1.5 , for P1, P2, P3 respectively) was lower than the control group (17.61 and 12.54 ), both at $37{ }^{\circ} \mathrm{C}$ and $40^{\circ} \mathrm{C}$. Similarly, Vmax of the neonates at risk of sepsis treated with antibiotics $(0.46,0.34,0.04$ and $0.07,0.20,0.24)$ was lower than the control group (1.47 and $0.53)$ at $37^{\circ} \mathrm{C}$ and $40^{\circ} \mathrm{C}$.

Conclusion: The study shows that the Catalase activity at the saliva of newborns at risk of sepsis treated with antibiotic was lower than the control group.
'Child Health Department, Ulin General Hospital/Faculty of Medicine, Universitas Lambung Mangkurat, Banjarmasin, Indonesia

${ }^{2}$ Department of Biochemistry, Faculty of Medicine, Universitas Lambung Mangkurat,

Banjarmasin, Indonesia

*Corresponding to: Pricilia Gunawan Halim. Child Health Department, Ulin General Hospital/Faculty of Medicine, Universitas Lambung Mangkurat, Banjarmasin, Indonesia. pricilia.gh@gmail.com
Received: 2020-06-27 Accepted: 2020-08-12 Published: 2020-08-26

\section{INTRODUCTION}

Neonatal sepsis remains the highest cause of neonatal morbidity and mortality despite much progress in the management of neonatology. ${ }^{1,2}$ In developing countries, the number of neonatal deaths due to sepsis is 34 per 1000 live births, mainly occur in the first week of life. ${ }^{3}$ In Indonesia, the infant mortality rate is 19 per 1000 live births, or around 236 babies die every day. Neonatal sepsis contributes to $20.6 \%$ deaths at the first 28 days and about $12 \%$ deaths at the first six days. ${ }^{4}$

Neonatal sepsis is a clinical syndrome of a systemic disease that is accompanied by bacteremia and occurs in the first month of life. This condition could be defined clinically and/or microbiologically by positive blood or cerebrospinal fluid cultures. ${ }^{5}$ In neonatal sepsis, the activation of leukocytes and inflammatory cells results in massive production of reactive oxygen species (ROS) in the body. ${ }^{6}$ Initially, ROS are generated by enzymes as a defense mechanism against infective agents. ${ }^{7}$ Hydrogen peroxide $\left(\mathrm{H}_{2} \mathrm{O}_{2}\right)$ is part of the enzymatic, mechanical defense that can be found in blood and saliva. ${ }^{8}$ It is not specific and can harm the patient because it is also toxic to human cells. ${ }^{9}$ The production of ROS in neonatal sepsis has been documented in various studies, including our previous studies that have shown an increase in ROS such as peroxide in neonatal sepsis. ${ }^{10}$ The increased ROS level is one of the predisposing factors for disease severity. ${ }^{11}$

An excessive increase in ROS will activate endogenous enzymatic antioxidants such as Catalase (CAT) to prevent the accumulation of ROS in the body. ${ }^{12}$ Human Catalase belongs to the monofunctional catalase group that contains heme, which is present in almost all aerobic organisms. Catalase is mainly intracellular (in cells) with the highest concentration found in red blood cells, liver, kidneys, and saliva. ${ }^{13,14}$ Catalase is a tetrametric protein with a molecular weight of $244 \mathrm{kDa}$ and symmetricity of 222, consisting of four identical subunits weighing $59.7 \mathrm{kDa}$. Each subunit contains 527 amino acid residues, a heme group called iron (III) protoporphyrin IX, and a tightly bound 
NADPH molecule. Catalase is responsible for the decomposition of $\mathrm{H}_{2} \mathrm{O}_{2}$ into water and oxygen. Under prolonged exposure to $\mathrm{H}_{2} \mathrm{O}_{2}$, Catalase binds to $\mathrm{NADPH}$, oxidizes $\mathrm{NADPH}$ to $\mathrm{NADP}+$ and its activity falls to one-third of its initial activity. ${ }^{13}$

Ampicillin, Gentamicin or a combination of both are the first-line antibiotics that have been widely used in the management of neonatal sepsis. ${ }^{15,16}$ In its development, it is believed that antibiotic therapy plays a certain role in the production of ROS and the disruption of enzymatic antioxidants activity such as catalase (CAT). ${ }^{17-19}$ There have been several studies on the effects of antibiotic therapy on catalase activity. The study of Dwyer et al. proves that bactericidal antibiotics dynamically alter cellular respiration and induce lethal levels of $\mathrm{H}_{2} \mathrm{O}_{2}$. On the other hand, antioxidants significantly reduce the process of killing cells by antibiotics. ${ }^{17}$ However, how antibiotics affect the endogenous enzymatic defense system or vice versa remains unknown to date. This research will measure the saliva catalase kinetic parameters in neonates at risk of sepsis and the effect of antibiotics on the CAT kinetic parameters in vitro.

\section{METHODS}

The study was conducted in February-June 2015 at the neonatal intensive care department of the Ulin General Hospital Banjarmasin. Biochemical analysis was carried out in the biochemistry laboratory of the Faculty of Medicine, Universitas Lambung Mangkurat, Banjarmasin, Indonesia. The samples include 20 neonates, consisting of 5 healthy infants (without risk factors for sepsis) as a control group and 15 infants at risk of sepsis. Infants with sepsis risk were defined as newborns with at least one major risk factor and or two minor risk factors. Major risk factors were: premature rupture of membranes $>24$ hours, intrapartum fever with temperature $>38^{\circ} \mathrm{C}$, chorioamnionitis, fetal heart rate $>160$ times/minute and persistent, smelly green amniotic fluid. Minor risk factors were: premature rupture of membranes $>12$ hours, intrapartum fever $>37.5^{\circ} \mathrm{C}$, low APGAR score ( < first 5 minutes, $<$ fifth 7 minutes), very low birth weight ( $<1500$ grams), gestational age $<37$ weeks, multiple pregnancies, itchy vaginal discharge with a foul smell, mothers with urinary tract infections or suspected untreated urinary tract infections. ${ }^{8}$

About three $\mathrm{ml}$ saliva specimens were taken from the oropharynx of each neonates using mucus extractor/suction according to the standard neonatal resuscitation procedures. The parents were informed about the study and has given written consent prior to the procedure. The procedure has been approved by local Ethical commission prior to the study. The saliva from the control group was mixed with $\mathrm{H}_{2} \mathrm{O}_{2}$ (Saliva $+\mathrm{H}_{2} \mathrm{O}_{2}$ ), Saliva samples from infants at risk of sepsis were divided into three groups, $\mathrm{P} 1$ (Saliva $+2 \mathrm{mg}$ ampicillin $+\mathrm{H}_{2} \mathrm{O}_{2}$ ), $\mathrm{P} 2$ (Saliva $+0.2 \mathrm{mg}$ Gentamicin $+\mathrm{H}_{2} \mathrm{O}_{2}$ ), and P3 (Saliva $+2 \mathrm{mg}$ ampicillin $+0.2 \mathrm{mg}$ gentamicin + $\mathrm{H}_{2} \mathrm{O}_{2}$ ). All the solutions were incubated at $37^{\circ} \mathrm{C}$ and $40^{\circ} \mathrm{C}$ for an hour.

Catalase activity was measured by the Aebi method using a spectrophotometer at a wavelength of $240 \mathrm{~nm} .{ }^{20}$ The activity was defined as the amount of $\mathrm{H}_{2} \mathrm{O}_{2}$ (in mmol) used per minute in a phosphate buffer solution $(50 \mathrm{mM}, \mathrm{pH} 7)$. The study was conducted at two different temperatures, $37^{\circ} \mathrm{C}$ dan $40^{\circ} \mathrm{C}$. The kinetic parameters were determined based on five different substrate concentrations of $\mathrm{H}_{2} \mathrm{O}_{2}$. The substrate concentrations used were $10,20,30,40$ and $50 \mathrm{mM}$. Kinetic parameters in the form of Michaelis-Menten constant $(\mathrm{Km})$ and maximum speed (Vmax) were determined using the Lineweaver-Burk plot of the Michaelis-Menten equation, which is as follows:

$$
\frac{1}{V}=\frac{k m}{V \max } \times \frac{1}{[S]}+\frac{1}{V \max }
$$

$\mathrm{V}$ is the reaction speed, Vmax is the maximum reaction speed, $\mathrm{Km}$ is the Michaelis-Menten constant which represents the number of substrates needed to reach half the reaction rate, and $S$ is the substrate concentration. ${ }^{21}$

\section{RESULTS}

The overall CAT activities in two different temperature were shown in Table 1 and plotted in Figure 1 and 2. The Lineweaver-Burk plot (Figure 1 and 2) shows the reverse graph of the substrate concentration plotted against the inverse of the $\mathrm{H}_{2} \mathrm{O}_{2}$ reaction rate. Figure 1 and 2 also show the linear regression equation and correlation index (r) for each group. Table 1 shows the Km and Vmax values calculated through the linear regression equation obtained from each group. It can be seen that the $K m$ value of the treatment groups (P1, P2, P3) is lower than the control group. This means that the administration of antibiotics reduces the $\mathrm{Km}$ value of salivary Catalase.

\section{DISCUSSION}

The value of $\mathrm{Km}$ is determined by the concentration of the enzyme, and kinetically describes the enzyme affinity for the substrate. The smaller the $\mathrm{Km}$ value, the higher the affinity between the enzyme and 


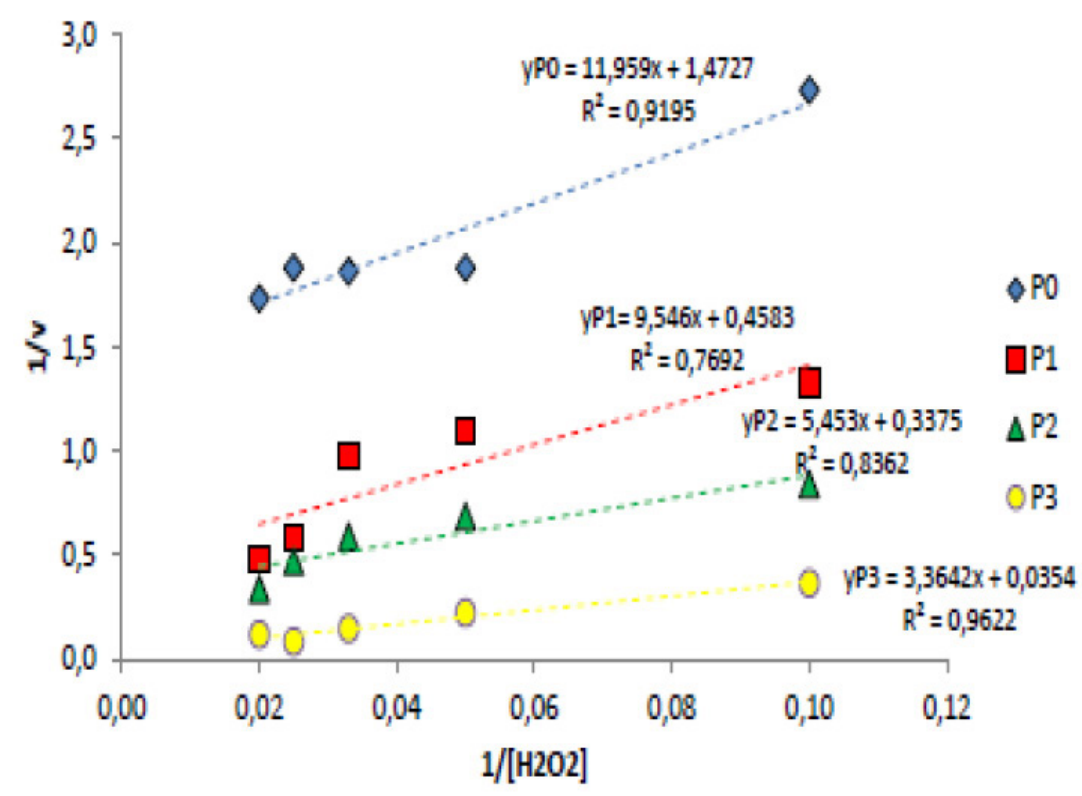

Figure 1. Lineweaver-Burk plot of the four groups at $37^{\circ} \mathrm{C}$.

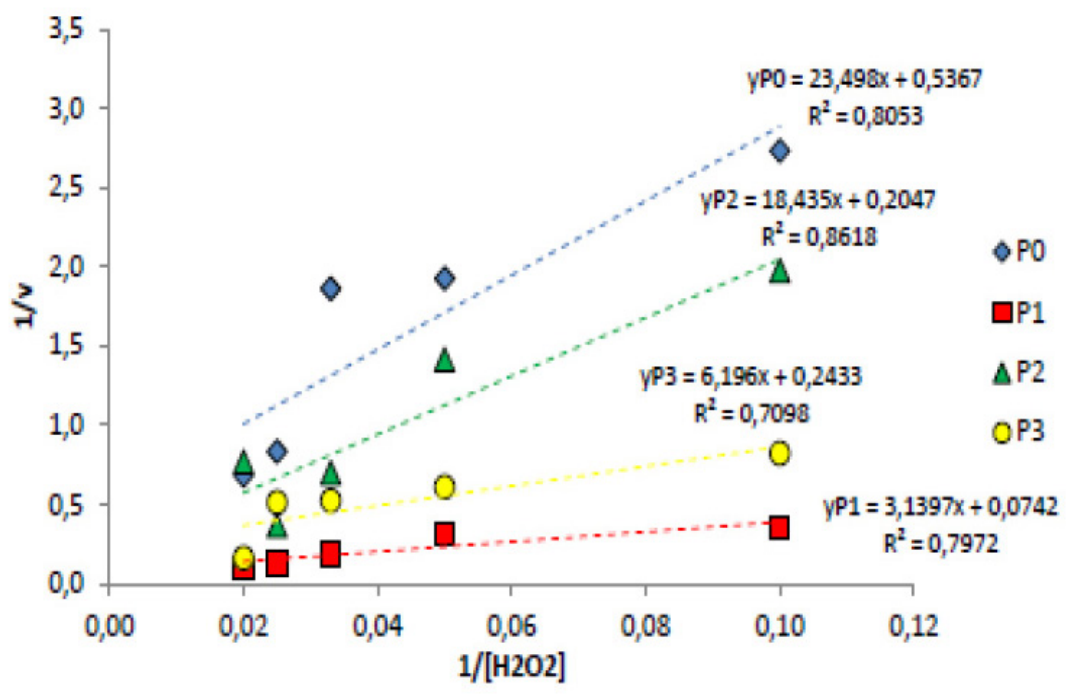

Figure 2. Lineweaver-Burk plot of the four groups at $40^{\circ} \mathrm{C}$

Table 1. Effect of treatment on CAT kinetic parameters and correlation coefficient between substrate concentration and CAT activity

Temperature

\begin{tabular}{ccccccc} 
Group & \multicolumn{3}{c}{$\mathbf{3 7 ^ { \circ } \mathrm { C }}$} & \multicolumn{3}{c}{$\mathbf{4 0 ^ { \circ } \mathbf { C }}$} \\
\cline { 2 - 7 } & $\mathbf{K m}$ & $\boldsymbol{V m a x}$ & $\mathbf{r}$ & $\boldsymbol{K m}$ & $\boldsymbol{V m a x}$ & $\mathbf{r}$ \\
\hline P0 & 17.61 & 1.471 & 0.959 & 12.545 & 0.532 & 0.899 \\
\hline P1 & 4.369 & 0.456 & 0.878 & 0.232 & 0.074 & 0.893 \\
\hline P2 & 1.840 & 0.337 & 0.915 & 3.742 & 0.203 & 0.928 \\
\hline P3 & 0.119 & 0.035 & 0.981 & 1.504 & 0.243 & 0.843 \\
\hline
\end{tabular}

Km: Michaelis-Menten constant; Vmax: maximum reaction rate;

r: correlation coefficient of substrate concentration against Catalase activity. the substrate. $\mathrm{Km}$ indirectly shows the catalytic efficiency of the enzyme. The higher the value of $\mathrm{Km}$, the better the catalysis power of the enzyme on the substrate..$^{21}$ The result of the study indicates that the administration of antibiotics can affect the activities of enzymatic endogen by increasing the affinity of CAT- $\mathrm{H}_{2} \mathrm{O}_{2}$ complex in saliva. Nevertheless, it can be concluded that antibiotic therapy, including Ampicillin, Gentamicin, and a combination of both, can increase the affinity of CAT-H2O2. The highest affinity was found in the P3 group (a combination of ampicillin and Gentamicin), while the lowest affinity was found in the control group $(\mathrm{P} 0)$ at $37^{\circ} \mathrm{C}$ (Table 1).

Ampicillin and Gentamicin have been used as a combination of antibiotics in empirical therapy for neonatal sepsis when bacteriological culture results are yet available. Ampicillin is a penicillin derivative and belongs to the beta-lactam group. It is bactericidal and potent, especially against gram-positive bacteria. Ampicillin is different from penicillin because of its amino group structure. The amino group in ampicillin helps the drug to penetrate the outer membrane of gram-negative bacteria. Ampicillin works as a competitive inhibitor of the transpeptidase enzymes that bacteria need to form cell walls. Ampicillin inhibits the bacterial cell wall synthesis. ${ }^{22}$ On the other hand, Gentamicin is a bactericidal aminoglycoside antibiotic. Gentamicin inhibits bacterial protein synthesis by binding to the bacterial ribosomal site. Gentamicin is used mainly for gram-negative bacterial infections. ${ }^{23}$ The combination of Ampicillin and Gentamicin results on synergistic action against various pathogens that cause sepsis such as Group B Streptococcus (GBS), Enterococci, Listeria monocytogenes, Enterobacteriaceae (Enterobacter spp., Proteus spp., Escherichia coli). This combination has been used as a first-line treatment for neonatal sepsis in both developing and developed countries. ${ }^{24}$

The result of this study shows that the administration of antibiotics (ampicillin and Gentamicin) indirectly helped the defense mechanism by increasing the $\mathrm{H}_{2} \mathrm{O}_{2}$ level in saliva. In vitro studies show that bactericidal antibiotics increase oxidative stress by directly inducing the ROS formation. ${ }^{19,25}$ One of the induction mechanism is believed to be through the Fenton reaction. ${ }^{17}$ In this study, Ampicillin and Gentamicin have been shown to increase ROS indirectly through CAT inhibition. The $\mathrm{Km}$ and Vmax value of CAT in this study decreased in the treatment group, especially in the P3 group with a combination of ampicillin and Gentamicin. Furthermore, the $K m$ value decreased more than the Vmax value in all treatment groups. This indicates that CAT inhibition is more likely to 
occur due to increased enzyme-substrate affinity than interference with CAT catalytic ability. This study also investigated the effects of temperature exposure on CAT kinetic parameters. Km and Vmax values were lower in all treatment groups at $40^{\circ} \mathrm{C}$ (Table 1). These results indicate that the increase in temperature also affects the increased affinity of the CAT- $\mathrm{H}_{2} \mathrm{O}_{2}$ complex of saliva with antibiotics.

\section{CONCLUSION}

Based on the findings above, it can be concluded that Ampicillin and/or Gentamicin reduce the value of $\mathrm{Km}$ and Vmax salivary Catalase in neonatal with a risk of sepsis. It is believed that Ampicillin and Gentamicin play a role in inhibiting Catalase by increasing the affinity of the CAT- $\mathrm{H}_{2} \mathrm{O}_{2}$ complex.

\section{CONFLICT OF INTEREST}

All authors declare there is no conflict of interest.

\section{AUTHOR CONTRIBUTION}

All authors have contributed substantially during all phases of the study, involve in drafting and revising the manuscript, giving final approval and have agreeing to be accountable.

\section{FUNDING}

All authors have no external support or funding to report.

\section{REFERENCES}

1. Yunanto A, Firdaus RT, Triawanti, Suhartono E. Advance Oxidation Protein Products (AOPPs) of Newborn at Risk of Sepsis as Novel Parameter for Early-Onset Neonatal Sepsis. Int J Biosci Biochem Bioinforma. 2014;4(2):90-3. Available from: http://dx.doi.org/10.7763/ijbbb.2014.v4.317

2. Pramana KP, Kardana IM, Nilawati GAP. Diagnosis Accuracy of Hematological Scoring System in Early Identification of Neonatal Sepsis. Bali Med J. 2016;5(3):139.

3. Kardana IM. Incidence and factors associated with mortality of neonatal sepsis. Paediatr Indones. 2011;51(3):144. Available from: http://dx.doi.org/10.14238/ pi51.3.2011.144-8

4. Hayun M. The Risk Factors of Early Onset Neonatal Sepsis. Am J Clin Exp Med. 2015;3(3):78. Available from: http:// dx.doi.org/10.11648/j.ajcem.20150303.11

5. Shaha CK, Dey SK, Shabuj KH, Chisti J, Mannan MA, Jashimuddin M, et al. Neonatal Sepsis - A Review. Bangladesh J Child Heal. 2012;36(2):82-9. Available from: http://dx.doi.org/10.3329/bjch.v36i2.13084

6. Cherian S, Jameson S, Rajarajeswari C, Helena V, Latha L, Anu Rekha MR, et al. Oxidative stress in sepsis in children. Indian J Med Res. 2007;125(2):143-8.

7. Battino M, Ferreiro MS, Gallardo I, Newman HN, Bullon P. The antioxidant capacity of saliva. J Clin Periodontol. 2002;29(3):189-94. Available from: http://dx.doi. org/10.1034/j.1600-051x.2002.290301x.x

8. Ihalin R, Loimaranta V, Tenovuo J. Origin, structure, and biological activities of peroxidases in human saliva. Arch Biochem Biophys. 2006;445(2):261-8. Available from: http://dx.doi.org/10.1016/j.abb.2005.07.004

9. Valerio TA, Cancelier AC, Constantino L, Petronilho F, Ritter C, Dal-Pizzol F. Inflammatory and Oxidative Cord Blood Parameters as Predictors of Neonatal Sepsis Severity. Rev Bras Ter Intensiva. 2012;24(1):30-4. Available from: http://dx.doi.org/10.1590/s0103-507x2012000100005

10. Yunanto A, Firdaus RT, Triawanti T, Suhartono E. Salivary Antioxidative Index in Newborns at Risk of Sepsis as Novel Parameter for Early-Onset Neonatal Sepsis. J Med Bioeng. 2014;3(1):63-6. Available from: http://dx.doi. org/10.12720/jomb.3.1.63-66

11. Rocha M, Herance R, Rovira S, Hernandez-Mijares A, M. Victor V. Mitochondrial Dysfunction and Antioxidant Therapy in Sepsis. Infect Disord - Drug Targets. 2012;12(2):161-78. Available from: http://dx.doi. org/10.2174/187152612800100189

12. Sayed ZM El, Abou EHS, Abd EAA, Dalia T. Study of Antioxidants' Enzymes Kinetics, Superoxide Dismutase, Glutathione Peroxidase and Catalase, in Neonatal Sepsis. J Adv Med. 2013;2(2):81-90. Available from: https://www.indianjournals.com/ijor. aspx? target $=$ ijor:jam\&volume $=2$ \&issue $=2 \&$ article $=004$

13. Kodydková J, Vávrová L, Kocík M, Žák A. Human catalase, its polymorphisms, regulation and changes of Its activity in different diseases. Folia Biol (Czech Republic). 2014;60(4):153-67.

14. Miricescu D, Greabu M, Totan A, Didilescu A, Rădulescu R. The antioxidant potential of saliva: Clinical significance in oral diseases. Ther Pharmacol Clin Toxicol. 2011;15(2):139_43. Available from: http://www.terapeutica.ro/img/art/ pdf/82/OP7.Miricescu.pdf

15. Tzialla C, Borghesi A, Serra G, Stronati M, Corsello G. Antimicrobial therapy in neonatal intensive care unit. Ital J Pediatr. 2015;41:27. Available from: https://pubmed.ncbi. nlm.nih.gov/25887621

16. Bibi S, Chisti MJ, Akram F, Pietroni MAC. Ampicillin and Gentamicin are a useful first-line combination for the management of sepsis in under-five children at an urban hospital in Bangladesh. J Health Popul Nutr. 2012;30(4):487-90. Available from: https://pubmed.ncbi. nlm.nih.gov/23304915

17. Dwyer DJ, Belenky PA, Yang JH, Cody MacDonald I, Martell JD, Takahashi N, et al. Antibiotics induce redox-related physi. Proc Natl Acad Sci U S A. 2014;111(20):E2100-9. Available from: https://www.pnas.org/content/111/20/ E2100

18. Dwyer DJ, Kohanski MA, Hayete B, Collins JJ. Gyrase inhibitors induce an oxidative damage cellular death pathway in Escherichia coli. Mol Syst Biol. 2007;3(1):91. Available from: https://onlinelibrary.wiley.com/doi/ abs/10.1038/msb4100135

19. Kohanski MA, Dwyer DJ, Hayete B, Lawrence CA, Collins JJ. A Common Mechanism of Cellular Death Induced by Bactericidal Antibiotics. Cell. 2007;130(5):797-810.

20. Aksoy Y, Balk M, Üfi HÖ, Özer N. The Mechanism of Inhibition of Human Erythrocyte Catalase by Azide. Turkish J Biol. 2004;28(2-4):65-70.

21. Shang ZC, Zhang LL, Wu ZJ, Gong P, Li DP, Zhu P, et al. The activity and kinetic parameters of oxidoreductases in phaeozem in response to long-term fertiliser management. J Soil Sci Plant Nutr. 2012;12(3):605-15. Available from: $\quad$ https://scielo.conicyt.cl/scielo.php?script=sci_ arttext\&pid=S0718-95162012000300019\&lng=es\&nrm=is o\&tlng=en

22. Sharma SK, Singh L, Singh S. Comparative Study between Penicillin and Ampicillin. Sch J Appl Med Sci. 2013;1(4):291-4. Available from: www.saspublisher.com 
23. Rahim ASA, Sayuti MIM, Hau KC, Ee DCC, Zaki WNRW, Raskitar N, et al. An Illustrated Review About Aminoglycosides. WebmedCentral Pharm Sci. 2011;2(12):1-14.

24. Darmstadt GL, Batra M, Zaidi AKM. Parenteral Antibiotics for the Treatment of Serious Neonatal Bacterial Infections in Developing Country Settings. Pediatr Infect Dis J. 2009;28(Supplement):S37-42. Available from: http:// dx.doi.org/10.1097/inf.0b013e31819588c3
25. Páez PL, Becerra MC, Albesa I. Effect of the association of reduced glutathione and ciprofloxacin on the antimicrobial activity in Staphylococcus aureus. FEMS Microbiol Lett. 2010;303(1):101-5. Available from: https://pubmed.ncbi. nlm.nih.gov/20030722/

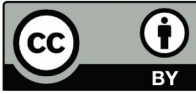

This work is licensed under a Creative Commons Attribution 